Electronic version of an article published as International Journal of Innovation Management, 22, 2, 2018 (c) copyright World Scientific Publishing Company https://www.worldscientific.com/doi/abs/10.1142/ S1363919618500184 


\title{
ORGANISATIONAL FACTORS, ANTICIPATED RENTS AND COMMERCIALISATION IN SMES
}

\author{
Hang Do, Tim Mazzarol, Geoffrey N Soutar, Thierry Volery, Sophie Reboud
}

\begin{abstract}
The study investigates the relationship between organisational factors and the anticipated returns to the commercialisation of an innovation within small to medium enterprises (SMEs). Using a large multi-country sample, the analysis involved a structural equation model of seven organisational factors associated with the management of innovation, and their relationship with the anticipated volume of sales, profitability and lifecycle of the innovation. Significant relationships were found between the possession of an innovation strategy and formal commercialisation management, and optimism over sales volumes and lifecycle. The study provides new insights into the resource-based view and theory of entrepreneurial rents, strengthening SME owner-managers' assessment on future investments in innovation and how to utilise their best capabilities. Policy makers also gain more insights into the commercialisation process within SMEs to foster the innovation orientation in both high and low tech sectors.
\end{abstract}

Keywords: Innovation, commercialisation, rent, organisational factors, SMEs

\section{Introduction}

This study examines the interrelationships between organisational factors and the perceived return to investment by owner-managers of small to medium enterprises ${ }^{1}$ (SMEs) engaged in the commercialisation of innovation. It provides new insights into the resource based view (RBV) of the firm (Barney, 2001); particularly its application to the assessment and organisation of entrepreneurial rents in SMEs engaged in innovation commercialisation (Alvarez and Barney, 2004; Alvarez, 2007). The study used Adams et al.'s (2006) conceptual model and Duhamel et al.'s (2014) approach to examine the relationships between organisational factors associated with the management of innovation, and the perceptions owner-managers have in relation to the anticipated 'rent' returns to future investment in innovation.

An SME owner-manager's ability to identify and exploit potential opportunities is an important determinant of their success in commercialising an innovation (Kirzner, 1997). However, this success is often based on informal and intuitive thinking, due to a lack of information and capacity to assess innovation risks and returns (Lindman, 2002; Duhamel et

\footnotetext{
${ }^{1}$ A small to medium enterprise (SME) is defined here as an independent business with fewer than 250 employees (OECD, 2004).
} 
al., 2014). SMEs also frequently lack a systematic approach to commercialisation, reducing their chance of success (Wheelen and Hunger, 1999). Although this issue has been widely discussed in recent years, little research has examined how SMEs make strategic decisions about investing in innovation and commercialisation activities (Mazzarol and Reboud, 2011; Mazzarol et al., 2014; Terziovski, 2010).

From a micro-level perspective, organisational issues and resource allocation are critical to an innovation's success (Teece, 2006; Cordero, 1990). Their importance lies in their ability to build a firm's core competences (Prahalad and Hamel, 1990). Adams et al. (2006) suggested innovation management has seven interconnected elements (inputs, knowledge management, innovation strategy, organisational culture and structure, portfolio management, project management, and commercialisation). Each is a resource bundle that can be used to improve innovation activities. Although an ability to allocate resources to achieve successful innovation in small entrepreneurial firms is recognised conceptually (Alvarez and Busenitz, 2001; Alvarez, 2007), relatively little research has examined the relationship between the deployment of resources and how SME owner-managers assess potential returns to investment in innovation. This gap led to the present study that investigates the interaction between the organisational factors and the SMEs' estimate of an innovation's sales volume, profitability and length.

\section{Literature Review}

Tidd (2001) highlighted the challenge facing researchers in generating "clear and consistent findings or coherent advice to managers" in relation to "best practice" in the management of innovation. This "challenge" was due to the complex nature of how innovation occurs within an organisation, and the need to consider the interplay between at least four major factors. The first of these is the level of uncertainty and complexity within a firm's task environment. The second is the nature of the innovation being commercialised (e.g. incremental, radical or disruptive). Third is the firm's organisational configuration (e.g. structure and processes). While the fourth is the firm's organisational performance (e.g. rate of growth, market share). According to Tidd (2001), the better the alignment between these factors in the management of innovation the better a firm's performance.

Tidd (2001) also suggested a firm's internal organisational factors and external linkages play a key role in determining how well it performs. Although the logic of Tidd's (2001) analysis is sound, his discussion focused on large firms. Little attention has been given to SMEs in relation to this suggested nexus between organisational configuration, innovation management, and type of innovation being commercialised, which led to the present study. The following sub-sections provide a review of the relevant literature and conceptual foundations upon it was based.

\section{A resource-based view (RBV) of organisational factors influencing commercialisation}

A defining characteristic of most SMEs is that they are resource constrained, with a lack of technical, marketing, financial and managerial resources (Dahlstrand and Stevenson, 2007). This is particularly relevant in the new product development (NPD) and commercialisation 
processes in which SMEs need to make the best use of available resources and avoid the high risk of short production runs in response to immediate customer needs (Lindman, 2002).

The RBV concept is a firm-level management theory that suggests a firm's ability to generate above average returns comes from the efficient allocation and deployment of its rare, strategic and valuable resources (Barney, 1991; Crook et al., 2008). In addition, a firm's core competences are seen as key to its competitive advantage, enabling it to outperform competitors in a sustained way (Prahalad and Hamel, 1990). Technological capabilities, knowledge integration and marketing capabilities also contribute (Canto and Gonzalez, 1999; Plambeck, 2012). In addition, anticipated financial returns and the percentage of sales from new products are also important (Griffin and Page, 1996; Bobrow, 1997).

The RBV model provides a foundation for understanding the process of innovation management (Van der Panne, et al., 2003), particularly in SMEs (Tan, et al., 2009). It can also assist in understanding the behaviour of entrepreneurial firms (Alvarez and Busenitz, 2001). Mosey et al. (2000) used dynamic capabilities, which are a firm's ability to combine or modify resource bundles to sustain competitive advantage (Song et al., 2005), to explore innovation within SMEs. A firm's ability to effectively explore and exploit innovation also plays an important role (Yalcinkaya et al., 2007). However, the RBV is not without its critics and continues to evolve in relation to its research methodology and measurement (Hauschild and Knyphausen-Aufseß, 2013). First, there has not been a consensus on the definition of what constitutes a resource (Kraajienbrink et al., 2010). Second, prior RBV research has been criticised for focusing on large and established organisations, rather than on younger and smaller ventures (Ireland et al., 2005). Stevenson (1983) conceptualised entrepreneurship or small business as "the pursuit of opportunity," regardless of the resources controlled. Other scholars claim resources and the use of such resources might be applied differently in small and large firms (Wiklund and Shepherd 2009; Unger et al., 2011; Kellermanns et al., 2016).

Tidd's (2001) assessment of the influence of organisational configuration on innovation management pointed to the importance of devolution of decision making and the capacity of an organisation's structure to deal with complexity and uncertainty. Also important is a firm's ability to make best use of external linkages, particularly in the value chain (e.g. suppliers, customers). However, for SMEs the issue of devolution is usually moot, as these firms typically have simple organisational structures within which R\&D and commercialisation decision-making is the responsibility of the owner-manager or a small team (Hoffman et al., 1998). Such firms also need to make use of alliances to secure access to resources (Lasagni, 2012), and to creatively use of their existing resources when engaged in NPD (Berends et al., 2014).

\section{Management of innovation within SMEs}

Adams et al.'s (2006) review of management of innovation was not targeted at SMEs. However, it offers a useful framework through which to examine the effects organisational factors have on owner-managers' NPD and commercialisation decision making. It was used in this study to explore the relationships between the organisational configuration of the SMEs and the owner-managers' perceptions about the anticipated rent from their innovation activity. As noted earlier, Adams et al. (2006) suggested the process of managing innovation involves at least seven components and these are discussed in the following sub-sections. 


\section{Inputs management}

A firm's capacity to allocate and deploy strategic resources efficiently, so as to develop, manufacture and distribute products and services to customers is an important aspect of the management of innovation (Barney, 1991). Ideally these resources, or at least how they are bundled, should be rare, valuable and imperfectly imitable tangible and intangible resources (Mitchell and Zmud, 1999). SMEs can enhance their innovation outcomes through the acquisition of new technologies, particularly through alliances and cooperation (Al Ansari et al., 2014). The ability of SME managers to use their personal networks to identify and secure access to resources, in particular knowledge is also an important aspect of managing inputs (Sedighadeli and Kachouie, 2013). Where SMEs can access resources and ideas or information as to the best way to apply these to NPD, operations and marketing, the more likely it is that they will commit to innovation and commercialisation activities (De Zubielqui, Lindsay and O’Connor, 2014).

\section{Knowledge management}

A firm's ability to obtain and communicate ideas and information is also important to its ability to successfully manage innovation (Whittington et al., 1999). This includes a firm's ability to negotiate or 'bargain' with buyers and suppliers (Porter, 1980) and to work effectively with complementary actors (Aarikka-Stenroos and Sandberg, 2009; Mazzarol and Reboud, 2008). Marsh and Stock (2006) highlighted the significant role internal knowledge plays in improving NPD performance. In contrast, Menon and Pfeffer (2003) argued external knowledge is more valuable. Alegre et al. (2013) highlighted the significant effect knowledge management practices have on an SME's innovation performance, but suggested this relationship is mediated by a firm's "dynamic capabilities" in knowledge management. Such knowledge management capabilities help firms build a sustainable competitive advantage (Argote and Ingram, 2001) and impact on new product success (Palacios and José, 2006).

\section{Organisational culture}

Although it is one of the most difficult areas to measure and assess, organisational culture has been identified as a potential source of innovation and sustained competitive advantage (Barney, 1986). An organisation's culture has been defined as the values and beliefs shared and nurtured by organisational members (Miron et al., 2004). It has a significant impact on a firm's ability to innovate (Chandy and Tellis, 1998). An open and flexible culture improves the exchange of ideas internally and externally; promoting creativity and innovativeness (de Jong and Brouwer, 1999; McFadzean, 1998). Lee et al. (2008) reflected the same view, but suggested different levels of influence on different kinds of innovations. Organisational culture seems to stimulate innovation behaviour (Hartmann, 2006), but can lead to resistance to change (Boonstra and Vink, 1996). Hence, it is important to understand organisational culture to see how it influences an SME's innovation behaviour and their anticipated 
outcomes. It has previously been identified as important within large firms (Tushman and O’Reilly, 1997; Kenny and Reedy, 2006; Stock and Schnarr, 2015), although not necessarily as significant for SMEs engaged in innovation (Al Ansari et al., 2014).

\section{Innovation strategy}

Leadership and strategy in small, high-innovator firms is important for commercialisation success (Patton and Higgs, 2013). The commitment by a firm's senior management to NPD and commercialisation is crucial (Sedighadell and Kachquie, 2013). Prior research has also suggested a link between strategy and financial performance (Crespell and Hansen, 2008). Innovation strategy impacts on a firm's innovative capability and commitment to innovation investment (Cooper et al., 2004; Nybakk and Jenssen, 2012). According to Van de Ven (1986), firms with an innovation strategy are more likely to pursue a formal approach to innovation. Indeed, a strategic focus on innovation can be a source of competitive advantage and improved performance within firms (Jenssen and Randøy, 2006, Nybakk and Jenssen, 2012).

\section{Portfolio management}

The process of evaluating, choosing and monitoring investments and allocating funds is a portfolio management process important to innovation and commercialisation (Cooper, 2006; Yahaya et al., 2007). It enables "products and R\&D projects to be analysed in a systematic manner, providing the opportunity for the optimization of a company's long-term growth and profitability" (Mikkola, 2001, p. 42). Others have suggested a diversified portfolio of product and process innovation can positively impact on revenue (Athey and Schmutzler, 1995; Klingebiel and Rammer, 2014). Hauser et al. (2006) and Sorenson (2000) have also suggested that spreading resources among a number of projects has positive effects, which suggest managers should diversify investments (Keil et al. 2009) and use venture capital (Guler, 2007).

\section{Project management}

The efficiency of a firm's project management processes, including the tools used and the communication and collaboration used, also plays a role (Kerzner, 2006). Project success seems to be determined by the efficiency of communications and knowledge sharing (Hayashi, 2004) and by the effectiveness of coordination and control processes (Pons, 2008). The ability to integrate or systematically link NPD, commercialisation and technology evaluation processes is also important for success (Tugrul, 2013).

\section{Commercialisation}

The final commercialisation stage includes the processes used to introduce an innovation to the market (Herdman, 1995). Key elements are an ability to understand customers' needs (Huang, Soutar and Brown 2002), marketing skills (Adams et al., 2006) and IP protection (Candelin-Palmqvist et al., 2012; Burrone, 2005). Empirical evidence suggests a positive relationship between firms pursuing formal IP protection and innovation performance (Andries and Faems, 2013). Hence, a systematic and formal management of 
commercialisation is likely to influence anticipated returns. It is also important for firms to engage with customers after the launch of any new product or innovation in order to monitor performance and customer satisfaction (Millson, 2013).

\section{Commercialisation as a process}

The commercialisation process is poorly defined and often used synonymously with the separate, but related, NPD process (Aarikka-Stenroos and Sanberg, 2009). Commercialisation is associated with taking a new product to market and diffusing the innovation over time through marketing communication, brand development, sales and distribution; often driven by social capital networks (Lehtmäki, et al., 2008; Partanen, et al., 2008; Mitchell and Singh, 1996). It is where the investment made in innovation activities is realized and where the success or failure of such investments is determined (Park and Ryu, 2015). The competencies and resources required for successful commercialisation are operating routines for NPD, sales force management and distribution channels, customer service and support, the ability to maintain product and brand reputation, and the capacity to meet or even set industry benchmark standards and practice (Lee, 2009).

NPD and commercialisation in SMEs are often the outcomes of a "push-pull" or "cocreation" engagement with customers (Gibb and Scott, 1985), which is typically more informal than the processes used in larger firms (Cooper et al., 2004). While SMEs' organisational structures are usually adaptable, allowing rapid responses, these firms are often hamstrung by a lack of knowledge and a limited ability to develop the capabilities needed for commercialisation (Maes and Sels, 2015). However, if an SME can adapt its resources (in particular its knowledge-based capital), there are likely to be significant longterm performance benefits (Simsek and Heavey, 2011).

When an SME can secure "isolating mechanisms" through formal IP rights registration, or by technology specialization in market niches, it can enhance its performance and improve its chances of commercialisation success (Padula, et al., 2015; Kang et al., 2013). However, even when an SME lacks formal IP rights protection, it can achieve success if it can generate innovation capabilities by configuring its financial, physical and human resources in appropriate ways (Van Hemert, et al., 2013). Securing early market penetration and learning how to adapt more quickly than incumbents in a market and finding ways to cooperate with existing players who have complementary assets can lead to successful commercialisation outcomes (Gans and Stern, 2003). However, SME owner-managers need to evaluate the "economic rent" generated from any innovation and create innovation capabilities that help them develop and commercialise new products.

\section{The use of theories of economic rent within the commercialisation process}

The concept of economic rent can be traced back to nineteenth century economists, who defined it as "excess returns to resources that are in limited supply" (Schoemaker, $1990 \mathrm{p}$. 1179). Where a resource (either tangible or intangible) is in limited supply, but in high demand, it is possible for the owners of that resource to secure above average economic rents. Competitive advantage is derived from a firm's ability to secure control over resources that 
are commercially valuable, rare, difficult for competitors to copy and difficult for customers to substitute (Barney, 1991).

The ability of a firm, particularly an SME, to secure a competitive advantage through ownership of, or control over unique and valuable resources is difficult, and often possible only over a short-term period. These temporary rents, or $t$-rents, are more common than rents that can be sustainable over the long-term, or systematic rents (Schoemaker, 1990). Innovation, especially the ability to bundle existing resources together into new combinations, is a key way for firms - both large and small - to create resources that can be used as a foundation for securing competitive advantage.

This ability to apply creativity and enterprise to the generation of innovation rents is therefore a determinant of how successful a firm will be in securing and ultimately sustaining a competitive advantage. Innovation rent can be defined as "the return received in an activity that is in excess of the minimum needed to attract the resources to that activity" (Milgrom and Roberts, 1992, p. 621). This concept of innovation rent originates from the economic rent concept. It underlies SME owner-managers' commercialisation practices because it explains the nature of entrepreneurial behaviour and the strategic management of innovation by entrepreneurial SMEs (Alvarez and Barney, 2004).

From an innovation perspective, economic rent can include Ricardian and Schumpeterian rents. While the former arises from a firm's ability to control its tangible and intangible resources (Barney, 2001), the latter arises from a firm's dynamic capability to deploy and exploit these resources (Amit and Schoemaker, 1993). In fast-changing environments, Schumpeterian rent, also known as entrepreneurial rent, is more relevant (Lim et al., 2013).

Alvarez (2007) identified quasi-rents, which are created under conditions of risk but not uncertainty, and entrepreneurial rents, which are created under conditions of risk and uncertainty. When a firm can control the necessary resources to commercialise alone, the process is known as arbitrage. However, when a firm cannot proceed alone, and needs the collaboration of others who combine their resources, the process is known as entrepreneurship (Alvarez and Barney, 2004). Once an innovation has been commercialised and the value is appropriated, the rent can be deemed appropriable rent (Duhamel, et al., 2014).

\section{$<$ INSERT FIGURE 1 ABOUT HERE $>$}

Figure 1 provides a conceptual framework for assessing different types of economic rent an SME seeking to commercialise an innovation might consider. In the first stage, the ownermanager considers the innovation's potential rent (Duhamel et al., 2014) or entrepreneurial rent (Alvarez, 2007). Those that have relatively modest demands on a firm's resources and can be fully commercialised without outside resources will be arbitraged. However, the more radical the innovation, the greater the uncertainty and the less is the likelihood that an SME will be able to fully commercialise it alone. Under these conditions owner-managers will need to engage in an entrepreneurial strategy, and collaborate with others to secure needed 
financial, technical, market, human and/or intellectual resources (Mazzarol and Reboud, 2005).

Once an innovation enters the market, test marketing provides owner-managers with feedback and uncertainty is reduced. Under these conditions, entrepreneurial rent becomes quasi-rent (Alvarez, 2007) or residual rent (Santi, et al., 2003). Residual rent refers to the returns that take into account the analysis of the competitive strengths of the firm in commercialising the innovation. It considers the impact of environmental effects within the target market (i.e. bargaining power of buyers and suppliers, competition, government regulation), and the related erosion effects (i.e. substitutes, new market entrants) (Santi et al., 2003; Mazzarol and Reboud, 2005; Do, 2014; Do et al., 2014; Duhamel et al., 2014). Depending on available resources, a firm will follow an arbitrage or entrepreneurial strategy. The value captured is appropriable rent (Santi, et al., 2003; Duhamel, et al., 2014). If a firm has strong isolating mechanisms through the creation of explicit knowledge (e.g. patents), it will have an opportunity to control valuable assets, even if it has to collaborate with others (Alvarez and Barney, 2004). However, if it cannot control the necessary resources and its knowledge is tacit, or offers only weak isolating mechanisms, the firm's bargaining power will be low. A firm's ability to control the key resources needed for commercialisation will allow it to secure Ricardian rents. However, if such control is impossible, the firm will be forced to generate Schumpeterian rents in which the ability of the firm to collaborate with others, and co-create new value, will be essential.

Santi et al.'s (2003) framework has been used to examine how SMEs engage strategically in assessing an innovation's potential rent outcomes (Mazzarol and Reboud, 2006; Duhamel et al., 2014). The first component is the volume of anticipated sales, which is determined by the sector's potential, geographic diffusion, the size of user markets and limits to exploitation. The second is the rate of anticipated profit (gross and net) and the third is the length of the anticipated duration of the innovation's return, which depends on a firm's ability to put isolating mechanisms in place (Alvarez and Barney, 2004). This is an assessment of the firm's potential to generate rents from future investment of time and money into the innovation. It does not determine the actual rents generated from this investment. The importance of this stage in the commercialisation process should not be underestimated.

Shepherd and Patzelt (2017) suggest that although innovation is an essential component of entrepreneurship the two areas have tended to be examined separately within the academic literature. They point to the need to bring together the decision-making process undertaken by entrepreneurs in relation to innovation, with how they actually engage in the NPD process and the subsequent commercialisation of the innovation. They point to "operations management", or the process of how innovation is managed within the firm, as a key point of focus, and define this a "operational entrepreneurship", involving the selection and management of processes that can assist the entrepreneur to screen and assess the "potential value creation" from the exploitation of opportunities. Our study focusses on this aspect of how entrepreneurs assess the potential rents from the exploitation of an innovation and role played by NPD and associated processes.

Innovation, particularly radical innovation, involves the firm operating within an environment of high uncertainty. It is generally not possible for the firm's management to accurately assess the actual return to any investment made in an innovation. NPD and 
commercialisation processes typically adopt a "fuzzy front end" in which the potential of the innovation is explored (Koen et al., 2002). Any future investment is subject to a staged process in which market and technical factors are reviewed and "Go/Kill" or "Hold" decisions or "pivots" are made at different milestones (Ozer, 2004; Cooper and Kleinschmidt, 1993; Cooper and Edgett, 2009; Ries, 2011). These NPD systems, such as StageGate ${ }^{\circledR}$ (Cooper and Edgett, 2005; Cooper, 2008) provide the manager with a systematic approach to assessing the "risk-return" profile of their innovation at different milestones throughout the NPD process.

These systems are essentially a mechanism for reducing uncertainty, and as the process moves closer to the end sufficient information is usually available for reliable decision making over actual returns to investment (Cooper and Edgett, 2001). However, these systems have been designed around the practices of large firms and their application to small, innovator firms is a relatively recent development (Cooper, 2011). The ability for SME owner-managers to systematically assess the potential rents likely to be generated from their innovation at an early stage using a strategic rather than a financial assessment mechanism is therefore important, and that is where our study has its focus. Once the innovation has been inserted into the market it can benefit from the information and knowledge acquired, and that can be applied within the existing NPD process models such as StageGate ${ }^{\circledR}$ (Cooper, 2008) or Lean Start-up (Ries, 2011).

As illustrated in Figure 1, the initial stage of assessing the potential or entrepreneurial rent precedes the insertion into the market, once that stage is completed an assessment of the residual or quasi-rent can be made, before the final stage of assessing the appropriable rent. This process of assessing the "strategic fit" between the firm's market opportunities with its available resources, which takes place between the first and second stages in this model, is important. The resource scarcity that most SMEs face is why the RBV theories are important to understanding this process. Further, the interrelationship between the SME ownermanager's perceptions of the initial appropriable rent, and their firm's organisational configuration, is therefore important to understanding their decision-making process.

\section{Hypothesis development}

The preceding discussion suggests relationships between the seven organisational factors included in Adams et al.'s (2006) framework and owner-managers' anticipated rent, leading to three hypotheses, namely:

Hypothesis 1: There are positive relationships between each of the seven organisational factors and SMEs' estimate of an innovation's sales volume.

Hypothesis 2: There are positive relationships between each of the seven organisational factors and SMEs' estimate of an innovation's profitability (rate).

Hypothesis 3: There are positive relationships between each of the seven organisational factors and SMEs' estimate of the length of an innovation. 


\section{Methodology}

A partial least squares (PLS) analysis was used to estimate the hypothesized relationships between the variables measuring the organisational factors in the seven areas identified by Adams et al. (2006) as important to the management of innovation and the three components measuring anticipated rent, as proposed by Santi et al. (2003) and Duhamel et al. (2014). PLS is a variance-based SEM technique that generally performs well with non-normal data (Kock, 2010), which was seen as likely to be the case in this study. PLS is also recognised as a useful tool when the objective is prediction or exploratory modelling (Garson, 2014), as was the purpose here. PLS has been described as; "a soft modelling approach where no strong assumptions (with respect to the distributions, the sample size and the measurement scale) are required" (Esposito et al., 2010, p. 48). The WarpPLS program (Kock, 2012) was used to undertake the final analysis.

\section{Sampling and data collection}

The sample included 525 SME owner-managers operating in ten countries (Australia, Austria, Belgium, Canada, France, Italy, New Zealand, Spain, Switzerland and the USA). The sampling process was purposive and companies were selected on the basis of being SMEs (as defined by the EU and OECD with fewer than 250 employees). These firms were divided into micro-enterprises ( $<9$ employees), with 185 firms; small enterprises (10-49 employees), with 164 firms; and medium-enterprises (50-249 employees), with 176 firms.

Sampling across the different countries was even for seven of the ten countries, where sub-populations comprised an average of 13 percent of the total with a range from 9 to 18 percent. However, three countries (Italy, Spain and the United States) had smaller samples of between 2 and 5 per cent of the total. The firms were also divided into manufacturing (32\%), service and retailing (29\%), and specialist firms (37\%), the latter including firms in fields such as biotechnology, or information and communications technology.

While some firms were "hi-tech" (OECD, 2010), most were not. However, the average $R \& D$ investment as a proportion of annual turnover was 23 percent, reflecting a very high level of innovation investment or "R\&D intensity" (Cordero, 1990). Prior to the analysis cross-country and industry effects were examined using multiple regression analysis. This indicated there were no statistically significant differences between the sub-populations ( $p>0.05)$. Hence, such differences were not considered in our structural equation modelling analysis.

The data collection process was undertaken with the collaborative support of a multinational team of researchers working across 11 OECD countries. The data were collected through face-to-face interviews with the owner-manager or CEO of each firm. This project used a common questionnaire that was translated into multiple languages and each university partner team collected a number of cases using this instrument and a common research protocol. The full findings from the study and its data collection processes are outlined in Mazzarol and Reboud (2011). A comprehensive questionnaire was used that examined the nature of the firm's past track record in management innovation, how it was currently managing NPD and commercialisation and management's perception of the anticipated rent expected from an innovation they were planning to commercialise in the next 
three years. Questions were designed to measure the seven organisational factors identified by Adams et al. (2006), and the three components of the anticipated rent configuration (Santi et al., 2003; Duhamel et al., 2014). The face-to-face data collection allowed for a more rigorous assessment of the firms' commercialisation practices and processes, as well as overcoming any misinterpretation of the questionnaire items.

\section{Variables and measures}

Thirty items were used to measure the 10 constructs of interest (mostly through five-point Likert-type scales). The inputs construct was measured through four items that asked about the key technological, human, financial and physical resources firms use to innovate (Adams et al., 2006; Barney et al. (2001). The knowledge construct was measured through four items that asked about customers', suppliers' and competitors' bargaining powers (Porter, 1980). Organisational culture was measured through five items that asked about the firm's involvement with external stakeholders and employees (de Jong and Brouwer, 1999). The innovation strategy construct was measured through a single item that asked about the intensity with which the firm focused on generating innovations (Adams et al., 2006). The portfolio management construct asked about the types of innovations being developed. The project management construct was measured through five items adapted from Pons (2008) that measured the firm's project management team's experience, access to external expertise and government sponsorship of the innovation management process. The commercialisation construct was measured by four items that asked about the market testing of the innovation (Adams et al., 2006) and formal intellectual property protection, such as patents (Burrone, 2005).

The dependent variable (anticipated rent) was measured through the three aspects identified by Santi et al. (2003) and Duhamel et al. (2014) (i.e. volume, rate and length). Volume was measured by the geographic diffusion of the innovation, anticipated sales from the innovation in the first three years, and the anticipated diffusion of the innovation within targeted market segments. Rate was measured by gross profit margins, net profit margins and difficulties associated with the adoption of the innovation within its targeted market. Length was measured by the complexity of the technical base, the ability of the innovation to create isolating mechanisms based on its technical complexity and the firm's ability to place legal IP protection around the innovation.

\section{Analysis}

As can be seen in Table 1, the constructs' mean scores ranged from a high of 4.15 (strategy) to a low of 2.90 (length); suggesting there were a range of responses to the various constructs. This can also be seen in the standard deviations that ranged from 0.59 (culture) to 1.16 (commercialisation). Thus, it seems worthwhile to examine the suggested relationships.

\section{$<$ INSERT TABLE 1 ABOUT HERE >}

The measurement properties of the various constructs were assessed first to ensure they were acceptable before the hypothesized relationships were estimated. All of the multiple-item scales had acceptable reliability, as their composite reliability coefficients all exceeded 0.80 
(Fornell and Larcker, 1981). Further, the scales had convergent validity, as their average variance extracted (AVE) scores all exceeded 0.50 (Fornell and Larcker, 1981). Finally, as Fornell and Larcker (1981) have noted, discriminant validity can be assumed if the squared variance between a pair of constructs is less than their AVE scores. As the highest squared correlation (shared variance) within all of the various constructs pairs was 0.25 , while the lowest AVE score was considerably higher (0.56), it was safe to assume discriminant validity.

As common method bias can be an issue in cross-sectional studies, this issue was also examined. While a number of suggestions have been made to identify such bias (e.g. Harman's one factor test (Podsakoff and Organ, 1986) and Lindell and Whitney's (2001) marker variable approach), recent research has suggested the use of a full collinearity test when PLS is being used. Variance inflation factors (VIFs) are computed for each construct in the model and, if such VIFs are all less than 3.30, common method bias is not a problem (Kock, 2015). As the highest VIF in the estimated model was 1.94, common method bias was not an issue here.

\section{The Results}

The relationships between the seven organisational factors and anticipated volume, rate and length were estimated, with all variables being initially included. However, two did not have significant relationships (inputs and knowledge management) and were excluded. As shown in Figure 2, the strongest relationships were between commercialisation and length $(\beta=0.38$ $\mathrm{p}<0.01)$, innovation strategy and volume $(\beta=0.23 \mathrm{p}<0.01)$, and organisational culture and length $(\beta=0.20 \mathrm{p}<0.01)$. Organisational culture also had a significant relationship with volume $(\beta=0.18 \mathrm{p}<0.01)$ and rate $(\beta=0.14 \mathrm{p}<0.01)$. While commercialisation had a significant relationship with volume $(\beta=0.17 \mathrm{p}<0.01)$. Innovation strategy also had a significant relationship with length $(\beta=0.10 \mathrm{p}<0.01)$ and rate $(\beta=0.08 \mathrm{p}<0.01)$, while portfolio management had a significant relationship with length $(\beta=0.15 \mathrm{p}<0.01)$ and volume $(\beta=0.13$ $\mathrm{p}<0.01)$. Finally, project management had a modest relationship with length $(\beta=0.07 \mathrm{p}<0.05)$. It is worth noting that volume and length affected rate, with length $(\beta=0.24 \mathrm{p}<0.01)$ having a stronger influence than volume $(\beta=0.21 \mathrm{p}<0.01)$. The model explained $34 \%$ of the variance in rate and length and $22 \%$ of the variance in volume.

\section{<INSERT FIGURE 2 ABOUT HERE >}

\section{Discussion}

In examining these findings, a useful starting point is the relationships between the three components of the anticipated rent. As noted earlier, volume provides an assessment of the estimated volume of sales an innovation can make over a period of up to three years based on sales turnover, market share and geographic diffusion. Length is a measure of an innovation's ability to achieve a long product lifecycle based on isolating mechanisms created by its technical and legal complexity, while rate is a measure of the gross and net profit margin expected from an innovation and whether it offers a superior technical solution to existing designs. 
As illustrated in Figure 2, rate is influenced by length and volume, which suggests the owner-managers' perceptions of the durability of the innovation within the market and their outlook for future sales are the determinants of future profit margin projections. It is also worth noting that length had a slightly stronger $(\beta=0.24)$ influence over rate than did volume $(\beta=0.22)$, which suggests an innovation's ability to retain a long lifecycle due to superior design and difficulty to copy due to legal or technical factors may be more important when assessing anticipated rent. This highlights the relative importance of isolating mechanisms, such as patents or technical complexity (e.g. trade secrets), in extending an innovation's lifecycle, which is consistent with other research (Padula, et al., 2015; Kang, et al., 2013).

When the influence of the five significant organisational factors are examined against the three anticipated rent components, the most important in terms of influencing length is commercialisation $(\beta=0.38)$. This factor also has a significant - although weaker - influence on volume $(\beta=0.17)$. This highlights the importance of understanding customer or end-user needs and having a strong marketing orientation, which is consistent with earlier research (Burrone, 2005; Huang, Soutar and Brown, 2002; Candelin-Palmqvist et al., 2012; Millson, 2013). In addition, it emphasises the importance of SME owner-managers having a strong commitment to innovation, as this can help them improve sales through a stronger customer and market orientation (Huang et al., 2002). This supports the importance of systematic commercialisation processes and the generation of stronger IP protections that give ownermanagers stronger bargaining power when dealing with others (e.g. larger firms) during the commercialisation process (Alvarez and Barney, 2001; 2004).

Also, influencing length is project management, with a significant if somewhat modest influence $(\beta=0.07)$. This suggests good project management may offer SME ownermanagers greater confidence in their innovation's ability to deliver better design and stronger isolating mechanisms through technical and legal complexities. This finding is also consistent with earlier research (Hayashi, 2004; Kerzner, 2006; Pons, 2008, Tugrul, 2013).

As shown in Figure 2, both length and volume were also influenced by portfolio management. The level of influence was broadly similar and suggests owner-managers' assessment of the anticipated lifecycle and future sales and market share for their innovation is likely to be shaped by the nature of the innovation being commercialised (e.g. product, process, market, administrative). This supports Tidd's (2001) conceptual model that recognises the degree and type of innovation is important to the strategic innovation management process. It is also consistent with earlier research relating to the role of portfolio management in the commercialisation process (Athey and Schmutzler, 1995; Sorensen, 200; Hauser et al., 2006; Klingebiel and Rammer, 2014).

The influence innovation strategy has on volume $(\beta=0.23)$ was quite strong, suggesting SME owner-managers who make innovation a key part of their strategy, are likely to anticipate higher sales from future commercialisation investment. This is consistent with Covin and Prescott's research (1990). However, innovation strategy was also found to have significant, if weaker, influences on length $(\beta=0.10)$ and rate $(\beta=0.08)$, reflecting the importance of having senior management - in this case the owner-manager-committed to the commercialisation process (Sedighadell and Kachquie, 2013; Stock and Schnarr, 2016). It also suggests owner-managers who have a strong commitment to innovation as a key part of their firm's strategy will be more optimistic about their anticipated rent across the three 
components. The informality and "ad hoc" strategy formulation that typically characterises SME behaviour should be viewed as a learning process and owner-managers should be helped to develop their commercialisation knowledge and skills, as well as being helped to foster an innovation culture (Maes and Sels, 2014; Park and Ryu, 2015). This can serve to nurture knowledge-based capital, which can enhance the firms' capabilities in the commercialisation process (Simsek and Heavey, 2011). The influence of organisational culture is also worth noting. As shown in Figure 2, this organisational factor influenced all three components of the anticipated rent. This suggests an owner-manager's sense of the support for the innovation from within their firm influences anticipated rent, particularly likely profit, which is in line with prior research (Crespell and Hansen, 2008; Lawson and Samson, 2001).

Our study has focused on the relationship between the perceived returns or "rents" from an innovation, as seen by the owner-managers of innovator SMEs, and the organisational configuration and resources available to these decision makers. We have highlighted the need for firms on any size to approach NPD and commercialisation in a systematic "step-wise" process involving initial exploration via a "fuzzy front end", then a staged process in which "GO/KILL" decisions are made as more information is obtained and the relative uncertainty reduces (Koen et al., 2002; Cooper and Edgett, 2005, 2007; Cooper, 2008; 2011). As shown in Figure 1, this requires an initial assessment of the potential or entrepreneurial rent, then a subsequent assessment of the residual or quasi-rent following market insertion, and then the final assessment of the appropriable rent once the firm's available resources have been assessed. The findings from this study point to the importance of SMEs having a strategic commitment to innovation, supported by an organisational culture open to innovation, and strong systematic approaches to portfolio and project management and the commercialisation process. As illustrated in Figure 2, these organisational elements influence the assessment of the potential rents suggesting that SME owner-managers are more likely to have a positive assessment of their ability to commercialise an innovation if they have these strategic and cultural orientations towards innovation, and systematic approaches to NPD, present in their firms.

\section{Conclusions and Implications}

This study provides useful insights into the influence organisational factors have on the strategic assessments of SME owner-managers in relation to anticipated rents from investment in NPD and commercialisation activities. It highlights the importance of maintaining a strategic commitment to innovation and in doing so having a strong market orientation and listening to the voice of the customer (Griffin and Hauser, 1996; Dutta et al., 1999). It supports the RBV theory of entrepreneurial firms (Alvarez and Buzenitz, 2001; Alvarez and Barney, 2004; 2005), and the importance of owner-managers' having the right process for commercialisation, a supportive culture for innovation, knowledge of the likely market adoption rate and a general commitment to innovation as ways to obtain and maintain a competitive edge. 


\section{Limitations}

The study is not without limitations. Although the sample was large and drawn from a wide cross-section of SMEs across a number of countries, it was purposive and did not seek to represent all SMEs from within each country or industry. Although the face-to-face data collection process meant interviewers were able to ensure firms were genuinely engaged in commercialisation, and could help validate the owner-managers' responses, the sampling process was not random. Further, the study was cross-sectional in nature and only captured respondents' perceptions of how their innovations' commercialisation might generate an anticipated rent. It was not able to follow respondents through the commercialisation process and examine their responses once the market had provided an initial reaction to their new product.

\section{Implications for research}

Our empirical findings contribute to the existing, albeit somewhat limited, body of knowledge relating to the commercialisation processes of SMEs. The study provides empirical support for the theoretical frameworks of entrepreneurial rents (Alvarez and Barney, 2004; Alvarez, 2007) and links to organisational theory (Adams et al., 2006; Barney, 1991). The results support the significance of firm-level capabilities in stimulating anticipated innovation returns. The findings from this research also assist in helping close the divide within the academic literature, as identified by Shepherd and Patzelt (2017), between the entrepreneurship and innovation fields, by providing some new insights into the factors influencing entrepreneurial decision making within innovator SMEs.

Future research should explore the relationship between entrepreneurial orientation, optimism, and perceived risks and returns. A longitudinal analysis would also be beneficial, as this would deepen our understanding of entrepreneurs' behaviours when assessing innovation risks, and allow an examination of the decision making at different stages of the NPD process and how potential rents are modified into residual rents and finally appropriable rents. It is also important to examine the nature of innovation management in particular sectors and industries and to obtain a deeper view of their innovation orientation, competitiveness and anticipation of the market. Additionally, a further investigation into the influence organisational factors have on what SMEs achieve and what determines their ultimate success or failure would be useful, as it would strengthen our understanding of the factors contributing to differences in SMEs' perceived and actual returns. Finally, it would also be helpful to examine market and environment factors that influence the ways through which an innovation is commercialised. In this sense, it would be useful to further examine the impact of organisational factors on the assessment of residual rents and appropriable rents. Any differences between actual and anticipated outcomes could be related to interactions between organisational factors and environment turbulence, which might constrain or enhance SMEs' resources and capabilities to generate innovation returns.

\section{Implications for practice and policy}

The study provides SME owner-managers with a potential blueprint for assessing future investments in innovation. Our findings suggest formal commercialisation is important in 
helping owner-managers secure control over their technical and IP rights. As it creates isolating mechanisms that strengthen an SME's ability to negotiate with customers or partners. It can enhance a firm's ability to generate innovations that have longer lifecycles through the accumulation of competencies and know-how that produce technical platforms for developing radical innovations. In addition, our findings emphasise how firms can use their resources and capability to achieve targeted outcomes. For example, a firm that seeks a high volume of sales from innovation should focus on developing a strong innovation oriented strategy, while firm aiming to lengthen the life-cycle of innovation should use a formal process of commercialisation and foster an open cultural environment.

Owner-managers engaging in NPD and commercialisation need to make a strategic level decision as to their overall commitment to innovation as a competitive strategy. The risk associated with innovation, particularly radical innovation, is high and the owner-manager will need to ensure that they have a strong commitment to the pursuit of innovation as it will not necessarily prove an easy process. Owner-managers who see innovation as a key to their firm's long-term competitiveness will be more likely to allocate the necessary resources, engender the appropriate organisational culture, and commit to the development of systematic NPD and commercialisation processes.

For policy makers, the findings highlight the importance of fostering an innovation orientation within SMEs that views NPD and commercialisation as viable strategies for firms of all kinds and not just those in hi-tech sectors. An exploration of the organisational factors examined here provides policy makers with insights into SMEs' commercialisation needs, providing assistance in developing appropriate interventions that would simulate SMEs' innovation activities. However, policy should also recognise that SMEs lack the resources and often the experience of large-firms in relation to NPD and commercialisation. They need to develop appropriate systems for assessing the potential returns to any investment in innovation and use strategic rather than financial tools to assess risk and return. This is not to ignore the importance of financial assessments, but these generally cannot be undertaken in the early stage of an innovation project. It is only after the firm has had time to examine its market opportunity and match that against is resource capacity, that it can start to build a robust assessment of the actual returns to any investment. This requires a good deal of trial and error, with early engagement with customers or potential customers, as well as thirdparty organisations that might provide financial, technical or market resources otherwise unavailable to the SME owner-manager.

In addition to the fostering of an "innovation mindset" amongst SME ownermanagers, policy makers seeking to enhance the innovativeness of SMEs, should also provide support in enhancing their networks to third-party resource providers, as well as strengthening their NPD and commercialisation competencies through education and training programs. This can be done in a variety of ways. However, NPD and commercialisation programs, offered through universities, technology incubators and accelerators, offer not only management skills development, but also a focal point for connecting SME owner-managers to specialist networks able to provide technical assistance with NPD, as well as venture capital financing, marketing support and legal support for IP rights management in the commercialisation process. 


\section{References}

Aarikka-Stenroos, L., and B. Sanberg (2009). Applying network approach to commercialisation of innovations: Case study on nets to create markets for innovations. IMP2009 Conference, 3-5 September 2009, Marseilles, France.

Adams, R., J. Bessant., and R. Phelps (2006). Innovation management measurement: A review. International Journal of Management Reviews, 8(1), 21-47.

Al-Ansari, Y., J. Xu., and S. Pervan (2014). A Study of Organisational Determinants and Innovation Practices in Dubai SMEs. International Journal of Innovation Management, $18(1), 1-28$.

Alegre, J., K. Sengupta., and R. Lapiedra (2013). Knowledge management and innovation performance in a high-tech SMEs industry. International Small Business Journal, 31(4), 454-470.

Alvarez, S. A. (2007). Entrepreneurial rents and the theory of the firm. Journal of Business Venturing, 22(3), 427-442.

Alvarez, S. A., and J. B. Barney (2001). How can entrepreneurial firms really benefit from alliances with large firms? Academy of Management Executive, 15(1), 139-148.

Alvarez, S. A., and L. W. Busenitz (2001). The entrepreneurship of resource-based theory. Journal of Management, 27(12), 755-775.

Alvarez, S. A., and J. B. Barney (2004). Organizing rent generation and appropriation: Towards a theory of the entrepreneurial firm. Journal of Business Venturing, 19(5), 621635.

Amit, R., and P. J. Schoemaker (1993). Strategic assets and organisational rent. Strategic Management Journal, 14(1), 33-46.

Andries, P., and D. Faems (2013). Patenting activities and firm performance: Does firm size matter? Journal of Product Innovation Management, 30(6), 1089-1098.

Argote, L., and P. Ingram (2001). Knowledge transfer: A basis for competitive advantage in firms. Organisational Behaviour and Human Decision Processes, 82(1), 150-159.

Athey, S., and A. Schmutzler (1995). Product and process flexibility in an innovative environment. The Rand Journal of Economics, 26(4), 557-574.

Barney, J. B. (1986). Organizational Culture: Can it be a source of sustained competitive advantage? Academy of Management Review, 11(3), 656-665.

Barney, J. B. (1991). Firm resources and sustained competitive advantage. Journal of Management, 17(1), 99-120.

Barney, J. B. (2001). Is the resource-based view a useful perspective for strategic management research? Yes, Academy of Management Review, 26(1), 41-56. 
Berends, H., M. Jelinek, I. Reymen., and R. Stultiëns (2014). Product innovation processes in small firms: Combining entrepreneurial effectuation and managerial causation. Journal of Product Innovation Management, 31(3), 616-635.

Bobrow, E. E. (1997). The Complete Idiot's Guide to New Product Development, Macmillan, New York, NY.

Boonstra, J. J., and M. J. Vink (1996). Technological and organisational innovation: A dilemma of fundamental change and participation. European Journal of Work and Organisational Psychology, 5(3), 351-375.

Burrone, E. (2005). Intellectual property rights and innovation in SMEs in OECD countries. Journal of Intellectual Property Rights, 10(1), 34-43.

Candelin-Palmqvist, H., B. Sandberg., and U-M. Mylly (2012). Intellectual property rights in innovation management research: A review. Technovation, 32(9-10), 502-512.

Canto, J. G., and I. S. Gonzalez (1999). A resource-based analysis of the factors determining a firm's R\&D activities. Research Policy, 28(8), $891-905$.

Chandy, R. K., and G. J. Tellis (1998). Organizing for radical product innovation: The overlooked role of willingness to cannibalize. Journal of Marketing Research, 35(4), 474487.

Cooper, R. G. (2006). Formula for success in new product development. Marketing Management, 15(2), 18-24.

Cooper, R. G. (2008). The stage-gate idea-to-launch process update, what's new and NexGen systems. Journal of Product Innovation Management, 25(3): 213-232.

Cooper, R. G. (2011). Winning at new products: creating value through innovation. New York, Basic Books.

Cooper, R. G., and S. J. Edgett (2005). Lean, rapid and profitable new product development. Canada, Product Development Institute.

Cooper, R. G. and S. J. Edgett (2007). Generating Breakthrough New Product Ideas: Feeding the Innovation Funnel. Canada, Product Development Institute Inc.

Cooper, R. G., and S. J. Edgett (2009). Product Innovation and Technology Strategy. United States, Product Development Institute Inc.

Cooper, R. G., and E. J. Kleinschmidt (1993). Screening new products for potential winners. Long Range Planning 26(6): 74-81.

Cooper, R. G., S. J. Edgett, and E. J. Kleinschmidt (2001). Portfolio Management for New Product Development: Results of an Industry Practices Study." R\&D Management, 31(3): 361-380.

Cooper, R. G., S. J. Edgett., and E. J. Kleinschmidt (2004). Benchmarking best NPD practices - I. Research Technology Management, 47(1), 31-43. 
Cordero, R. (1990). The measurement of innovation performance in the firms: An overview. Research Policy, 19(2), 185-192.

Covin, J. G., and J. E. Prescott (1990). Strategies, styles, and structures of small product innovative firms in high and low technology industries. The Journal of High Technology Management Research, 1(1), 39-56.

Crespell, P., and E. Hansen (2008). Managing for innovation: Insights into a successful company. Forest Product Journal, 58(9), 6-17.

Crook, T. R., D. J. Ketchen Jr., J. G. Combs., and S. Y. Todd (2008). Strategic resources and performance: A meta-analysis. Strategic Management Journal,29(11), 1141-1154.

Dahlstrand, A. L., and L. Stevenson (2007). Linking innovation and entrepreneurship policy. Swedish Foundation for Small Business, Innovative Policy Research for Economic Growth (IPREG).

De Jong, J. P. J. and E. Brouwer (1999). Strategic study determinants of the innovative ability of firm's $R \& D$ activities, EIM, Zoetermeer.

De Zubielqui, G. C., N. Lindsay., and A. O'Connor (2014). How product, operations, and marketing sources of ideas influence innovation and entrepreneurial performance in Australian SMEs. International Journal of Innovation Management, 18(2), 1450017, 125.1

Do, T. H (2014). Determinants of innovation commercialization management and anticipated returns: An exploratory typology of SMEs. International Journal of Innovation and Technology Management, 11(06), p.1450042.

Do, T. H., T. Mazzarol., T. Volery, and S. Reboud (2014). Predicting anticipated rent from innovation commercialisation in SMEs. European Journal of Innovation Management, 17(2), 183-208.

Duhamel, F., S. Reboud., and M. Santi (2014). Capturing value from innovations: the importance of rent configurations. Management Decision, 52(1), 122-143.

Dutta, S., O. Narasimhan., and S. Rajiv (1999). Success in high-technology markets: Is marketing capability critical? Marketing Science, 19(4), 547-568.

Esposito Vinzi, V., W. W. Chin., J. Henseler., and H. Wang (2010). Handbook of partial least squares, Springer-Verlag, Berlin.

Fornell, C., and D. Larcker (1981). Structural equation models with unobserved variables and measurement error. Algebra and Statistics. Journal of Marketing Research, 18(3), 382388.

Gans, J. S., and S. Stern (2003). The product market and the market for "ideas: commercialisation strategies for technology entrepreneurs. Research Policy, 32(2003), $333-350$.

Garson, G. D. (2014), Partial least squares: Regression and structural equation models, Statistical Associates Publishing, www.statisticalassociates.com 
Gibb, A., and M. Scott (1985). Strategic awareness, Personal Commitment and the Process of Planning in the Small Business. The Journal of Management Studies, 22(6), 597-632.

Griffin, A., and A. L. Page (1996). PDMA success measurement project: Recommended measures for product development success and failure. Journal of Product Innovation Management, 13(6), 478-496.

Griffin, A., and J. R. Hauser (1996). Integrating R\&D and marketing: A review and analysis of the literature. Journal of Product Innovation Management, 13(3), 191-215.

Guler, I. (2007). Throwing good money after bad? Political and institutional influences on sequential decision making in venture capital industry. Administrative Science Quarterly, $52(2), 248-285$.

Hartmann, A. (2006). The role of organizational culture in motivating innovative behaviour in construction firms. Construction Innovation, 6(3), 159-172.

Hauschild, S., and D. Z., Knyphausen-Aufseß (2012). The resource-based view of diversification success: Conceptual issues, methodological flaws and future direction. Review of Managerial Science, 7(3), 327-363.

Hauser, J., G. J. Tellis., and A. Griffin (2006). Research on innovation: A review and agenda for marketing science. Marketing Science, 25(6), 687-717.

Hayashi, A. M. (2004). Building better teams. MIT Sloan Management Review, 45(2), 5.

Herdman, R. C. (1995). Innovation and commercialisation of emerging technologies, U.S. Congress, Office of Technology Assessment, OTA-BP-ITC-165, US Government Printing Office, Washington, DC.

Hoffman, K., M. Parejo, J. Bessant., and L. Perren (1998). Small firms, R\&D, technology and innovation in the UK: a literature review. Technovation, 18(1), 39-55.

Huang, X., G. N. Soutar., and A. Brown (2002). New product development processes in SMEs: Some Australian evidence. Journal of Small Business Management, 40(1), 27-42.

Ireland, R. D., J. W. Webb, and J. E. Coombs (2005). Theory and methodology in entrepreneurship research, in Research Methodology in Strategy and Management. (Eds). Ketchen. D. J., and D. D. Bergh. Bingley, UK: Emerald Group, 111-141.

Jenssen, J. I., and T. Randøy (2006). The performance effect of innovation in shipping companies. Maritime Policy and Management, 33(4), 327-343.

Kang, J., S-H. Gwon, S. Kim., and K. Cho (2013). Determinants of successful technology commercialisation: implication for Korean Government-sponsored SMEs. Asian Journal of Technology Innovation, 21(1), 72-85.

Keil, T., R. McGrath., and T. Tukiainen (2009). Gems from the ashes: capability creation and transformation in internal corporate venturing. Organisation Science, 20(3), 601-620. 
Kellermanns, F., J. Walter., T. Russell Crook., Kemmerer, B., and Narayanan (2016). The resource-based view in Entrepreneurship: A content- analytical comparison of researchers' and entrepreneurs' views. Journal of Small Business Management 54(1), 26-48

Kenny, B., and E. Reedy (2006). The impact of organisational culture factors on innovation levels in SMEs: An empirical investigation. Irish Journal of Management, 27, 119-142.

Kerzner, H. (2006). Project management: A system approach to planning, scheduling and controlling, Wiley, New York, NY.

Kirzner I. M. (1997). Entrepreneurial discovery and the competitive market process: An Austrian approach. Journal of Economic Literature, 35(1), 60-85.

Klingebiel, R., and C. Rammer (2014). Resource allocation strategy for innovation portfolio management. Strategic Management Journal, 35(2), 246-268.

Kock, N. (2010). Structural equation modelling made easy: A tutorial based on a behavioral study of communication in virtual teams using WarpPLS 1.0. IEEE International Professional Communication Conference, pp. 175-176.

Kock, N. (2012). WarpPLS 3.0 User Manual. ScriptWarp Systems, Laredo, TX.

Kock, N. (2015). Common method bias in PLS-SEM: A full collinearity assessment approach. International Journal of e-Collaboration, 11(4), 1-10.

Koen, P. A., G. M. Ajamian., S. Boyce., A. Clamen., E. Fisher., S. Fountoulakis., A. Johnson., P. Puri., and R. Seibert (2002). Fuzzy Front End: Effective Methods, Tools and Techniques. The PDMA ToolBook 1 for New Product Development. P. Belliveau, A. Griffin., and S. Somermeyer (Eds). New York, John Wiley \& Sons: Chapter 1.

Kraaijenbrink, J., J. C. Spender., and A. J. Groen (2010). The resource-based view: a review and assessment of its critiques. Journal of Management, 36(1), 349-372.

Lasagni, A. (2012). How can external relationships enhance innovation in SMEs? New evidence for Europe. Journal of Small Business Management, 50(2), 310-339.

Lawson, B., and D. Samson (2001). Developing innovation capability in organisations: A dynamic capabilities approach. International Journal of Innovation Management, 5(3), $377-400$.

Lee, C. K., B. Tan., and J. Z. Chiu (2008). The impact of organisational culture and learning on innovation performance. International Journal of Innovation and Learning, 5(4), 413428.

Lee, G. K. (2009). Understanding the timing of 'fast-second' entry and the relevance of capabilities in invention vs. commercialisation. Research Policy, 38(1), 86-95.

Lehtimäki, T., H. Simula., and J. Salo (2008). Clarifying the terms launch and commercialisation: Reflections from theory and practice. In proceedings of EMACConference 2008. 
Lim, D., N. Celly., E. Morse., and W. Rowe (2013). Rethinking the effectiveness of asset and cost retrenchment: The contingency effects of a firm's rent creation mechanism. Strategic Management Journal, 34(1), 41-61.

Lindell, M. K., and D. J. Whitney (2001). Accounting for common method variance in crosssectional research designs. Journal of Applied Psychology, 86(1), 114-121

Lindman, M. T. (2002). Open or close strategy in developing new products? A case study of industrial NPD in SMEs. European Journal of Innovation Management, 5(4), 224-237.

Maes, J., and L. Sels (2014). SMEs' radical product innovation: The role of internally and externally oriented knowledge capabilities. Journal of Small Business Management, 52(1), $141-163$.

Marsh, S. J., and G. N. Stock (2006). Creating dynamic capability: The role of intertemporal integration, knowledge retention, and interpretation. Journal of Product Innovation Management, 23(5), 422-436.

Mazzarol, T., and S. Reboud (2005). Customers as predictors of rent returns to innovation in small firms: An exploratory study. International Journal of Entrepreneurship and Innovation Management, 5(5-6), 483-494.

Mazzarol, T., and S. Reboud (2006). The strategic decision making of entrepreneurs within small high innovator firms. International Entrepreneurship and Management Journal, 2(2), 261-280.

Mazzarol, T., and S. Reboud (2008). The role of complementary actors in the development of innovation in small firms. International Journal of Innovation Management, 12(2), 223 253.

Mazzarol, T., and S. Reboud (2011). Strategic Innovation in Small Firms: An International Analysis of Innovation and Strategic Decision Making in Small to Medium-Sized Enterprises, Edward Elgar, Cheltenham, UK.

Mazzarol, T., D. Clark., S. Reboud., N. Gough., and P. Olson (2014). Perceptions of innovation climate and the influence of others: A Multi-country study of SMEs. International Journal of Innovation Management, 18(1), 1450009.

McFadzean, E. S. (1998). Enhancing creative thinking within organisations. Management Decision, 36(5), 309-315.

Menon, T., and J. Pfeffer (2003). Valuing internal vs. external knowledge: Explaining the preference for outsiders. Management Science, 49(4), 497-513.

Mikkola, J. H. (2001). Portfolio management of R\&D: Implications for innovation management. Technovation, 21(7), 423-435.

Milgrom, P., and J. Roberts (1992). Economics, Organisation and Management, Prentice Hall, Englewood Cliffs, NJ. 
Millson, M. R. (2013). Refinding the NPD/ innovation path to product market success with partial least squares path analysis. International Journal of Innovation Management, 17(2), 1350001, 1-23.

Miron, E., M. Erez., and E. Naveh (2004). Do personal characteristics and cultural values that promote innovation, quality, and efficiency compete or complement each other? Journal of Organisational Behavior, 25(2), 175-199.

Mitchell, V. L., and R. W. Zmud (1999). The effects of coupling it and work process strategies in redesigning projects. Organisation Science, 10(4), 424-438.

Mitchell, W., and K. Singh (1996). Survival of businesses using collaborative relationships to commercialise complex goods. Strategic Management Journal, 17(3), 169-196.

Mosey, S., J. N. Clare., and D. J. Woodcock (2002). Innovation decision making in British manufacturing SMEs. Integrated Manufacturing Systems, 13(3), 176-184.

Nybakk, E., and J. E. Jenssen (2012). Innovation strategy, working climate, and financial performance in traditional manufacturing firms: An empirical analysis. International Journal of Innovation Management, 16(2), 1-26.

OECD (2004). SME statistics: Toward a more systematic statistical measurement of SME behaviour, Background report for the second OECD Conference of Ministers Responsible for SMEs, Promoting entrepreneurship and innovative SMEs in a global economy, Istanbul, Turkey 3-5 June.

OECD (2010). Measuring Innovation: A New Perspective. Paris, Organisation for Economic Co-operation and Development.

Ozer, M. (2004). Managing the Selection Process for New Product Ideas. Research Technology Management, 47(4): 10-11.

Padula, G., E. Novelli., and R. Conti (2015). SMEs inventive performance and profitability in the markets for technology. Technovation, 41-42(2015), 38-50.

Palacios M. D., and F. José Garrigós Simón (2006). The effect of knowledge management practices on firm performance. Journal of Knowledge Management, 10(3), 143-156.

Park, T., and D. Ryu (2015). Drivers of technology commercialisation and performance in SMEs. Management Decision, 53(2), 353-338.

Partanen, J., K. Möller., M. Westerlund., R., Rajala., and A. Rajala (2008). Social capital in the growth of science-and-technology-based SMEs. Industrial Marketing Management, $37(5), 513-522$.

Patton, D., and M. Higgs (2013). The role of shared leadership in the strategic decision making processes of new technology based firms. International Journal of Innovation Management, 17(4), 1350015, 1-24.

Plambeck, N. (2012). The development of new products: The role of firm context and managerial cognition. Journal of Business Venturing, 27(6), 607-621. 
Podsakoff, P. M., and D. W. Organ (1986). Self-reports in organisational research: Problems and prospects. Journal of Management, 12(4), 531-544

Pons, D. (2008). Project management for new product development. Project Management Journal, 39(2), 82-97.

Porter, M. E. (1980) Competitive strategy: Techniques for Analysing Industries and Competitors, The Free Press, New York, NY.

Prahalad, C. K., and G. Hamel (1990). The core competence of the corporation. Harvard Business Review, 68(4), 79-91.

Ries, E. (2011). The Lean Startup: How constant innovation creates radically successful businesses. London, Portfolio Penguin Books.

Santi, M., S. Reboud., H. Gasiglia., and A. Sabouret (2003). Modèle de valorisation et de protection intellectuelle des innovations, HEC/INPI.

Schoemaker, P. J. H. (1990). Strategy, complexity and economic rent. Management Science, 36(10), 1178-1192.

Sedighadell, S., and R. Kachquie (2013). Managerial factors influencing success of new product development. International Journal of Innovation Management, 17(5), 1350022, $1-23$.

Shepherd, D., and H. Patzelt (2017). Trailblazing in Entrepreneurship: Creating New Paths for Understanding the Field. Cham, Switzerland, Palgrave Macmillan.

Shepherd, D., and J. Wiklund (2009). Are we comparing apples with apples or apples with oranges? Appropriateness of knowledge accumulation across growth studies. Entrepreneurship Theory and Practice 33(1), 105-123.

Simsek, Z., and C. Heavey (2011). The mediating role of knowledge-based capital for corporate entrepreneurship effects on performance: A study of small- to medium-sized firms. Strategic Entrepreneurship Journal, 5(1), 81-100.

Song, M., C. Droge., S. Hanvanich., and R. Calantone (2005). Marketing and technology resource complementarity: An analysis of their interaction effect in two environmental contexts. Strategic Management Journal, 26(3), 259-276.

Sorenson, O. (2000). Letting the market work for you: an evolutionary perspective on product strategy. Strategic Management Journal, 21(5), 577-592

Stevenson, H. H. (1983). A Perspective on Entrepreneurship. Boston, MA: Harvard Business School.

Stock, R. M., and N. L. Schnarr (2016). Exploring the product innovation outcomes of corporate culture and executive leadership. International Journal of Innovation Management, 20(1), 1650009, 1-33. 
Tan, J., E. Fischer., R. Mitchell., and P. Phan (2009). At the center of action: Innovation and technology strategy research in the small business setting. Journal of Small Business Management. 7(3), 233-262.

Teece, D. J. (2006). Reflect from "profiting from innovation". Research Policy, 35(8), 11311146.

Terziovski, M. (2010). Innovation practice and its performance implications in small and medium enterprises (SMEs) in the manufacturing sector: A resource-based view. Strategic Management Journal, 31(8), 892-902.

Tidd, J. (2001). Innovation management in context: Environment, organisation and performance. International Journal of Management Reviews, 3(3), 169-183.

Tugrul, U. D. (2013). Are formal technology and integration processes needed for successful product innovations? International Journal of Innovation Management, 17(4), 1350016, 121.

Tushman, M. L., and C. A. O'Reilly (1997). Winning Through Innovation: A Practical Guide to Leading Organisational Change and Renewal. Cambridge, UK: Harvard Business School Press.

Unger, J. M., A. Rauch., M. Frese., and N. Rosenbusch (2011). Human capital and entrepreneurial success: A meta-analytical review. Journal of Business Venturing, 26(3), 341-358.

Van De Ven, A. (1986). Central problems in the management of innovation. Management Science, 32(5), 590-607.

Van der Panne, G., C. van Beers., and A. Kleinknecht (2003). Success and failure of innovation: A literature review. International Journal of Innovation Management, 7(3), 309-338.

Van Hemert, P., P. Nijkamp., and E. Masurel (2013). From innovation to commercialisation through networks and agglomerations: analysis of sources of innovation, innovation capabilities and performance of Dutch SMEs. The Annals of Regional Science ${ }_{2} 50(2), 425-$ 452.

Wheelen, T. L., and J. D. Hunger (1999). Strategic management and business policy, Addison-Wesley, Reading, MA.

Whittington, R., A. Pettigrew., S. Peck., E. Fenton., and M. Conyon (1999). Change and complementarities in the new competitive landscape: A European panel study, 1992-1996. Organisational Science, 10(5), 653-600.

Yahaya, S.-Y., and N. Abu-Bakar (2007). New product development management issues and decision-making approaches. Management Decision, 45(7), 1123-1142.

Yalcinkaya, G., R. J. Calantone., and D. A. Griffith (2007). An examination of exploration and exploitation capabilities: Implications for product innovation and market performance. Journal of International Marketing, 15(4), 63-93. 
Tables and Figures

Table 1: The Constructs' Measurement Properties

\begin{tabular}{|c|c|c|c|c|c|c|}
\hline Variable & $\begin{array}{c}\text { Number } \\
\text { of } \\
\text { Items }\end{array}$ & Mean & SD & $\begin{array}{l}\text { Lowest } \\
\text { Loading }\end{array}$ & Composite Reliability & AVE Score \\
\hline Inputs & 4 & 3.73 & 0.77 & 0.66 & 0.84 & 0.57 \\
\hline Knowledge Management & 4 & 3.43 & 0.78 & 0.72 & 0.85 & 0.58 \\
\hline Organisational Culture & 4 & 3.94 & 0.59 & 0.72 & 0.88 & 0.64 \\
\hline Innovation Strategy & 1 & 4.15 & 1.04 & na & na & na \\
\hline Portfolio Management (dummy) & 1 & na & na & na & na & na \\
\hline Project Management & 3 & 3.66 & 0.89 & 0.64 & 0.81 & 0.58 \\
\hline Commercialisation & 4 & 3.01 & 1.16 & 0.63 & 0.83 & 0.56 \\
\hline Volume (Sales) & 3 & 2.97 & 0.97 & 0.70 & 0.81 & 0.58 \\
\hline Rate (Profit) & 3 & 2.96 & 0.91 & 0.53 & 0.84 & 0.64 \\
\hline Length (Lifecycle) & 3 & 2.90 & 0.83 & 0.80 & 0.83 & 0.61 \\
\hline
\end{tabular}




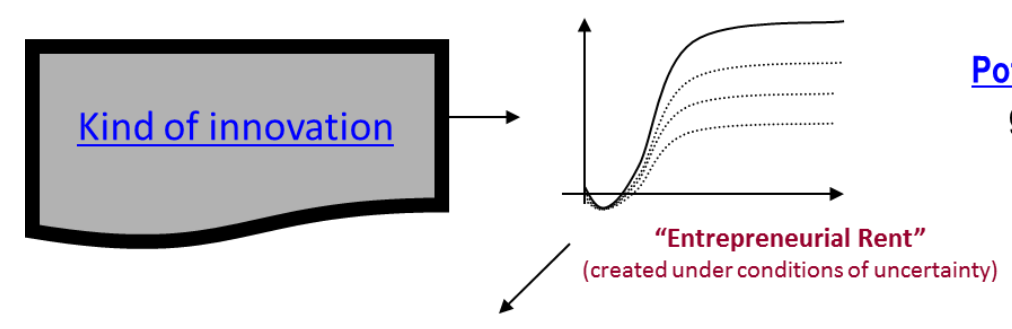

\section{Potential Rent may be}

generated by the

innovation

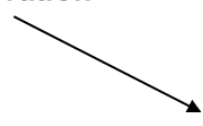

Residual Rent, progressively eroded when inserted:

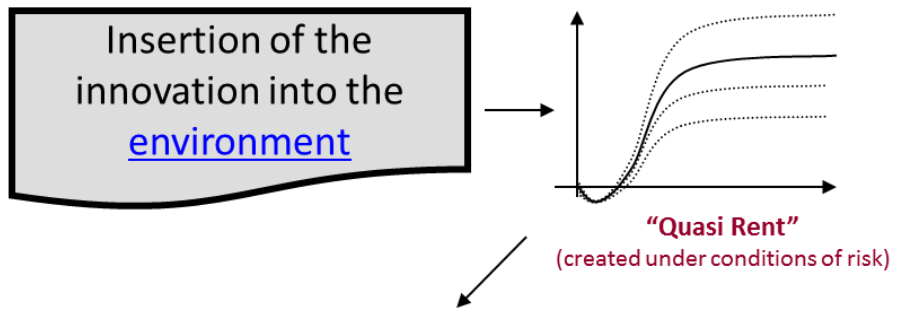

- into a business

- in the competitive game

- and taking in account the competencies and resources of the innovator

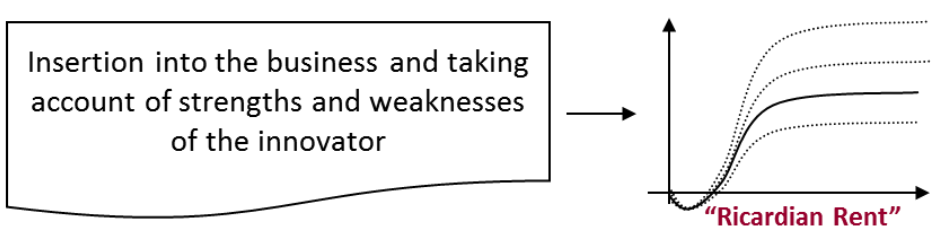

OR

"Schumpeterian Rent"

Figure 1: Conceptual framework of different economic rent configurations 


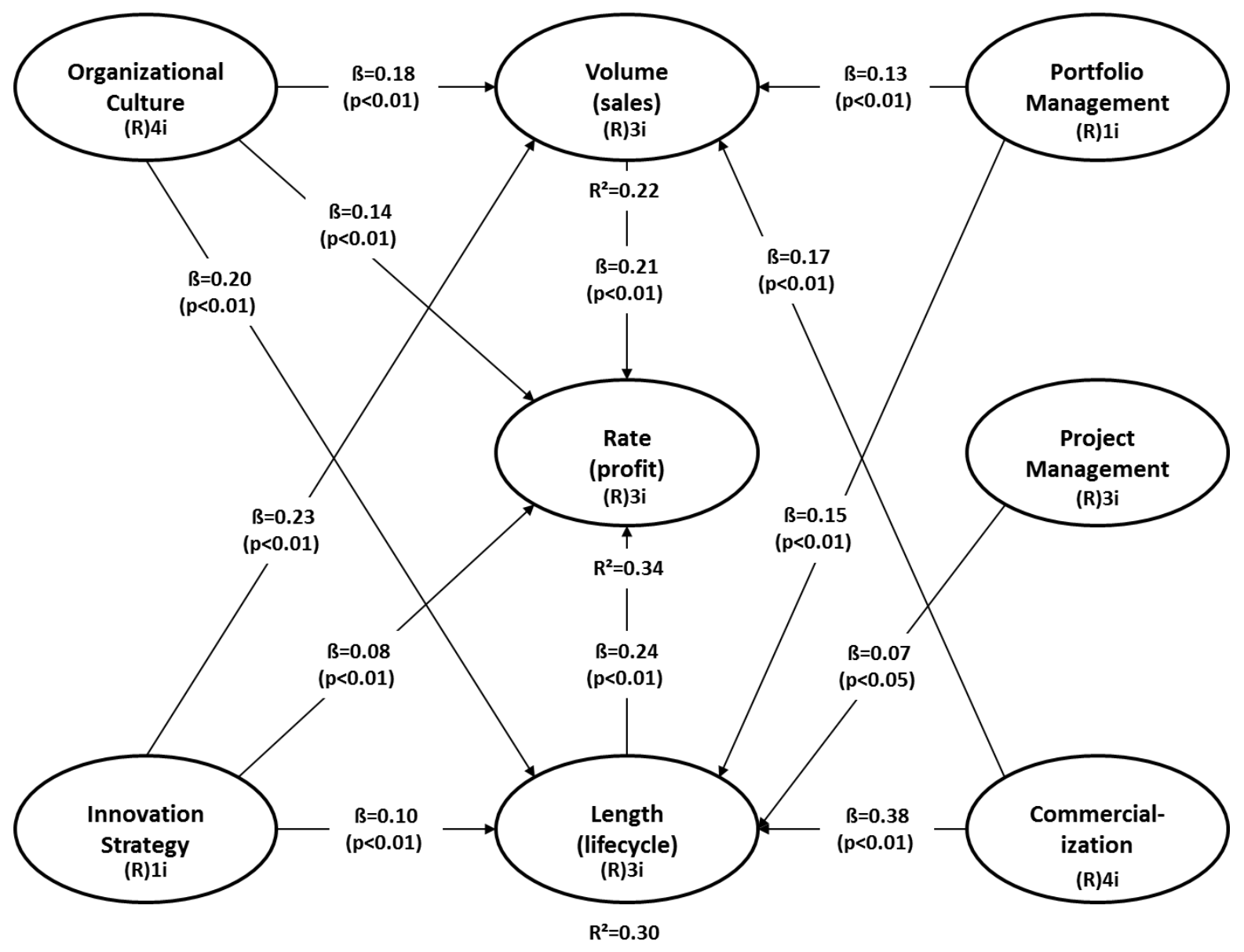

Figure 2: The PLS model 